\title{
Milk peptides: effect on the enzymatic hydrolysis of sodium caseinate
}

\author{
ZAHUR U. HAQUE and PIRKKo ANTILA
}

\begin{abstract}
HAQUE, Z. U. \& ANTILA P. 1993.Milk peptides: effect on the enzymatic hydrolysis of sodium caseinate. Agric. Sci. Finl. 2: 371-378. (Department of Food Science and Technology, Mississippi State University, USA and Department of Food Technology, University of Helsinki, Finland.)

Sodium caseinate $(\mathrm{NaCN})$ was hydrolyzed using Rhozyme $41\left(\mathrm{Rh}_{41}\right)$, Neutrase (Neu) and plasmin (PL) to obtain peptide preparations termed; Na-Cas-P-Rh41, Na-Cas-P$\mathrm{Neu}$, and Na-Cas-P-Plasmin, respectively . Indigenous whey peptides (IWP) were obtained from fresh sweet whey, at different levels of ufconcentration, by a precipitation method described earlier. These peptide fractions were then used to observe their effect on the activity of some proteases. All peptide preparations depressed enzyme activity. $\mathrm{Na-Cas-P-Rh41}$ was the most powerful inhibitor of enzyme activity and decreased the activity of trypsin, Rh41, Neu, and PL by $15,32,50$, and $14 \%$, respectively. IWP markedly depressed activity of $\mathrm{Rh}_{41}$. The degree of uf-concentration of whey from which IWP was obtained was directly related to degree of inhibition.
\end{abstract}

Key words: peptide, casein, cheese, ripening, enzyme

\section{Introduction}

Enzymes play key roles in the manufacture of many foods (BEST 1987, WoNG et al. 1988). Dairy foods like yogurt, cheese, buttermilk, sour cream, acidophilus milk, Kefir cultured milk, and Kumiss are partly or fully dependent on enzyme action for the formation of desirable flavor and physico-chemical attributes (BEST 1987). The action of enzymes on dairy proteins (VISSER 1981), and the classification and mode of action of proteases in general, have been extensively reviewed (MORIHARA 1974, VISSER 1981, NEURATH 1985, YELLIN 1986).

Proteolytic activity is particularly important in the manufacture and aging of cheese (LAW and WigMORE 1982, PAHKALA et al. 1984). In order to accelerate the ripening process of cheese, various enzyme preparations are added (EXTERKATE et al. 1987, FOX 1989) at different stages of the process
(LAW and WigMORE 1982, LindE et al. 1989). Caseins form the network matrix of the cheese and contributes to the flavor. The rate and extent of hydrolysis of caseins influence the quality of cheese (Zevaco and Desmazeaud 1980, Banks et al. 1988, ChristenSEN et al. 1989). Enzymes have thus been used to influence both the quality and aging time of cheeses (LAW 1981, LAW and WIGMORE 1983). Unfortunately, use of enzymes may lead to the formation of off-flavors and of bitter peptides (FoX 1989). Bitter peptides detected from cheese are small and hydrophobic (VISSER et al. 1983, HURRELL et al. 1989). Such protein fragment are more likely to occur if the enzyme activity is high and the action is thorough.

Since the formation of the enzyme-substrate complex, i.e., protein-protein association, is a prerequisite for enzyme activity, molecules that interfere with the complex formation decrease/inhibit 
activity. Amphipathic peptides produced following enzyme hydrolysis of casein reduced protein-protein association (HAQUE and BoHOUA 1990). It would be useful for the industry, particularly for the cheese makers, to know whether such peptides may influence activity of ripening enzymes.

The objective of this part of the study was therefore to evaluate the influence of casein hydrolysates on the activity of some food enzymes. We have used uptake of base $(\mathrm{NaOH})$ as an indicator of the rate of hydrolysis. A pH-stat was used to monitor uptake as described earlier (ANTILA et al. 1987). The theoretical basis for the $\mathrm{pH}$ drop method in non-buffered suspensions has been elaborated (HUNG et al. 1984). Trypsin was chosen since it is considered safe in food applications and have been extensively studied, plasmin was used since it too has been well studies and is known to effect cheese quality ( LE-BARS and GRIPON 1989), and Neutrase and Rhozyme-41 were selected randomly from cheese ripening enzymes.

\section{Material and methods}

Fresh milk was obtained from the MSU Dairy Plant. Bio-Rad protein assay dye kit was obtained from Bio-Rad Chem. Div. Richmond, CA. Recrystallized urea, imidazole, 2-mercaptoethanol (2$\mathrm{ME}$ ), plasmin (P-7911)(EC 3.4.21.7) (PL), pepsin (P-6887) (EC 3.4.23.1) (PEP), and trypsin (T-8253) (EC 3.4.21.4) (TRY) were obtained from Sigma Chem. Co., St.Louis, MO. Rhozyme-4l (Rh-41) concentrate (factor 6.15) a proteolytic enzyme mixture was obtained from Genencor, South San Francisco, Ca. Neutrase (NEU), a proteolytic enzyme mixture (batch \#PW20502, activity 1.63 unit/g) was obtained from Novo Industries, Copenhagen, Denmark. Standard base for pH-stat was from E. Merck, Darmstadt, Germany. All other chemicals were analytic grade and obtained from recognized sources.

\section{Preparation of sodium-caseinate $(\mathrm{NaCN})$}

Fresh raw milk ( 1 1) was centrifuged at about 3000 $\mathrm{x} \mathrm{g}$ to remove fat and diluted 2 fold with water. The
$\mathrm{pH}$ was then adjusted to 4.6 with $1 \mathrm{~N} \mathrm{HCl}$ at $25^{\circ} \mathrm{C}$ and the resulting coagulum was filtered with a cheese cloth after standing for $30 \mathrm{~min}$. The casein thus obtained was washed and then redispered in distilled water (1 1) at $\mathrm{pH} 4.6$ and again filtered after $60 \mathrm{~min}$. The process of washing and redispersion was repeated. The acid casein was redispersed in distilled water by adding $1 \mathrm{M} \mathrm{NaOH}$ to adjust $\mathrm{pH}$ to 7 , acid precipitated followed by washing with acidified water. This final coagulum was redispersed in water at $\mathrm{pH} 7\left(25^{\circ} \mathrm{C}\right)$ (adjusted with $\left.\mathrm{NaOH}\right)$ and freeze dried after flash freezing in liquid nitrogen. The $\mathrm{NaCN}$ powder thus obtained was stored over dessicant at $-20^{\circ} \mathrm{C}$ until required.

\section{Preparation of milk peptides}

\section{Milk protein hydrolysate}

Casein hydrolysate were prepared from $\mathrm{NaCN}$ by enzyme action using PL, Rh-41, Neu, TRY, and PEP under conditions described in Table $1 . \mathrm{NaCN}$ (final concentration 3\%, w/v) was hydrated for an hour in distilled water, the $\mathrm{pH}$ was adjusted using $\mathrm{O} . \mathrm{IN} \mathrm{HCl}$ or $\mathrm{NaOH}$, temperature was equilibrated to $37^{\circ} \mathrm{C}$, and the freshly prepared aqueous enzyme solutlon was added to bring the final enzyme:protein concentration to 1:200. The hydrolysis was carried out for periods as listed in Table I and the reaction was stopped by heating at $85^{\circ} \mathrm{C}$ for $15 \mathrm{~min}$. The hydrolysate was flash frozen using liquid nitrogen, freeze dried and stored over desiccants at $-20^{\circ} \mathrm{C}$ until needed. The peptides thus obtained were termed as follows: Na-Cas-P-Rh41, Na-Cas-P$\mathrm{Neu}$, and $\mathrm{Na}-\mathrm{Cas}-\mathrm{P}-\mathrm{Plasmin}$ for peptides generated from $\mathrm{Rh}_{41}$, Neu and PL, respectively.

\section{Indigenous milk peptides}

Indigenous peptides in sweet whey (Edam) was concentrated by ultrafiltration (Romicon, $10 \mathrm{k}$-cut) to different concentration ( $1,1.5$ and 4 fold) and dried by freeze drying to obtain free flowing powders. The peptides in the WPC were isolated by a modification of the method of HAQUE and KINSELLA (1988) (Figure 1) as follows: The WPC pow- 
Table 1. Preparation of crude peptides from milk proteins. Reactions were stopped by heating to $85^{\circ} \mathrm{C}$ for $15 \mathrm{~min}$.

\begin{tabular}{lrrr}
\hline Enzymes & \multicolumn{1}{l}{$\begin{array}{l}\text { Enz:protein } \\
\text { ratio }\end{array}$} & Time & $\mathrm{pH}$ \\
\hline plasmin & $1: 200$ & 3 & 7.5 \\
rhozyme 41 & $1: 200$ & 3 & 7 \\
neutrase & $1: 200$ & 3 & 6 \\
\hline
\end{tabular}

der $(10 \mathrm{~g})$ was extracted twice $(150 \mathrm{ml} \times 2)$ with acidified methanol containing $0.1 \%(\mathrm{v} / \mathrm{v})$ redistilled HCL (single boiling point). Solids in the extract were removed by centrifugation $(1000 \mathrm{~g})$ and the supernatant was dried in partial vacuum at $35^{\circ} \mathrm{C}$ to yield an oily residue that was washed thrice (20 $\mathrm{ml} \mathrm{x} \mathrm{3)} \mathrm{with} \mathrm{cold} \mathrm{diethyl} \mathrm{ether}\left(-20^{\circ} \mathrm{C}\right)$ followed by further washing $(3 \times 20 \mathrm{ml})$ with cold acetone:diethyl ether (l:l, v/v ). The resulting peptide mixture was dried in a stream of nitrogen and stored in vacuum over phosphorus pentoxide until needed.

\section{Monitoring the digestibility of casein}

Proteolysis of sodium caseinate $(\mathrm{NaCN})$ was monitored using a pH-stat (Mettler, Memotitrator DL 40RC) attached to a chart recorder and a Mettler GA 44 printer. Optimum temperature was maintained by using a jacketed reaction vessel connected to a controlled temperature water bath. The full scale of the pH-Stat was equal to $400 \mu \mathrm{l}$ of $0.05 \mathrm{M}$ $\mathrm{NaOH}$ unless otherwise stated in the text.

The $\mathrm{NaCN}(3 \%$, w/v) $(20 \mathrm{ml})$ was allowed to equilibrate to optimum temperature $\left(37^{\circ} \mathrm{C}\right)$. Freshly prepared enzyme solution in cold water was then added $(0.3 \mathrm{ml})$ with constant stirring to bring the protein to enzyme ratio to $1: 200, \mathrm{w} / \mathrm{w}$. The uptake of base over a period of $300 \mathrm{sec}$ was recorded.

\section{Effect of peptide on proteolysis}

The effect of the various peptide preparations on the digestibility of $\mathrm{NaCN}$ was observed after adding 10 and $20 \%$ by weight of the peptide preparations to

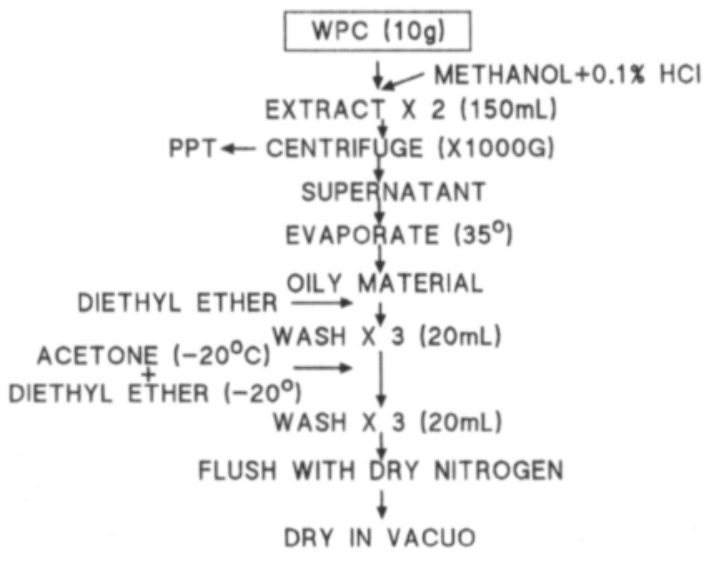

Fig. 1. Scheme of the isolation of indigenous milk peptides from whey protein concentrates (WPC) of various concentrations.

the protein dispersions. The mixture was mixed uniformly by "vortex" mixing and sonication prior to the experiment.

\section{Monitoring of hydrolysis}

\section{Polyacrylamide gel electrophoresis}

Very high-resolution polyacrylamide gel electrophoresis (VHR-PAGE) was carried out in the presence of SDS using a 10-20\% gradient gel (HAQUE and MOZAFFAR 1992a, b).

\section{High performance liquid chromatography (HPLC)}

HPLC of the hydrolysates was performed with a Bondaclone $10 \mathrm{C}_{18}$ column $(60 \mathrm{~cm} \times 0.7 \mathrm{~cm})$ (Phenomenex, CA) as described elsewhere (HAQUE and MOZAFFAR 1992b). Samples were eluted with a linear gradient where buffer A was 0.11 wt\% trifluoroacetic acid in double distilled water, and B was $90 \mathrm{wt} \%$ acetonitrile in water containing 0.1 wt $\%$ trifluoroacetic acid. An ISCO ChemResearch System containing a model 2360 gradient programmer (ISCO, Inc. USA) coupled with pressure regulators (Model 2350), $\mathrm{V}^{4}$ absorbance detector (ISCO), and refrigerated ISIS autoinjector, was used for monitoring the hydrolysis. 


\section{Determination of the N-Terminal Groups}

The degree of hydrolysis as a function of the free $\mathrm{N}$-terminal groups was determined by the modified OPA method of FRIESTER et al. (1989) (Table 2).

\section{Results and discussion}

Polyacrylamide gel electrophoresis showed highest apparent degree of hydrolysis of casein by $\mathrm{Rh}_{41}$ (Figure 2). The PAGE of hydrolysis with TRY, a powerful protease, has been shown as a comparison. It is clear that $R h_{41}$ was apparently as powerful, if not more powerful, than TRY. Hydrolysis by PL and NEU was much slower (data not shown). HPLC confirmed this observation for $\mathrm{Rh}_{41}$ (Figure 3) whereas peptides for NEU and PL were in trace amounts (data not shown). Based on the availability of $\mathrm{N}$-terminal groups, the degree of hydrolysis was Na-Cas-P-Rh ${ }_{41}>$ Na-Cas-P-Neu $>$ Na-Cas-p-plasmin (Table 2).

$\mathrm{Na}-\mathrm{Cas}-\mathrm{P}-\mathrm{Rh}_{41}$ and Na-Cas-P-Neu markedly reduced the rate of digestion of caseinate by TRY (Fig. 4). When the peptide concentration was increased to $20 \%$ (w/w casein), there was a concomitant increase in the inhibitive effect; $\mathrm{Na}-\mathrm{Cas}-\mathrm{P}-\mathrm{Rh}_{41}$ decreased activity rate of TRY by about $15 \%$ at an incubation time of $300 \mathrm{sec}$. The order of the depressing effect of the peptides remained the same; Na-Cas-P-Rh 41 > Na-Cas-P-NEU > Na-C-P-Plasmin. This is a significant observation because tryp$\sin$ is a powerful protease (Fig. 2), and we have used an enzyme to protein concentration of 1:200 which is relatively high.

When $\mathrm{Rh}_{41}$ was used to hydrolyze casein, the most active activity suppressants were again $\mathrm{Na}$ Cas-P- $\mathrm{Rh}_{41}$ and $\mathrm{Na}-\mathrm{Cas}-\mathrm{P}-\mathrm{Neu}$, the latter being

Table 2. Degree of proteolysis of crude peptide preparations from sodium caseinate. Determined by the method of FIESTER et al. (1989).

\begin{tabular}{lrr}
\hline Peptide & Enzyme & Degree, $\%$ \\
\hline Cas-P-Plasmin & plasmin & $<1$ \\
Cas-P-Neut & netrase & 7.0 \\
Cas-P-RH41 & rhozyme-41 & 9.2 \\
\hline
\end{tabular}

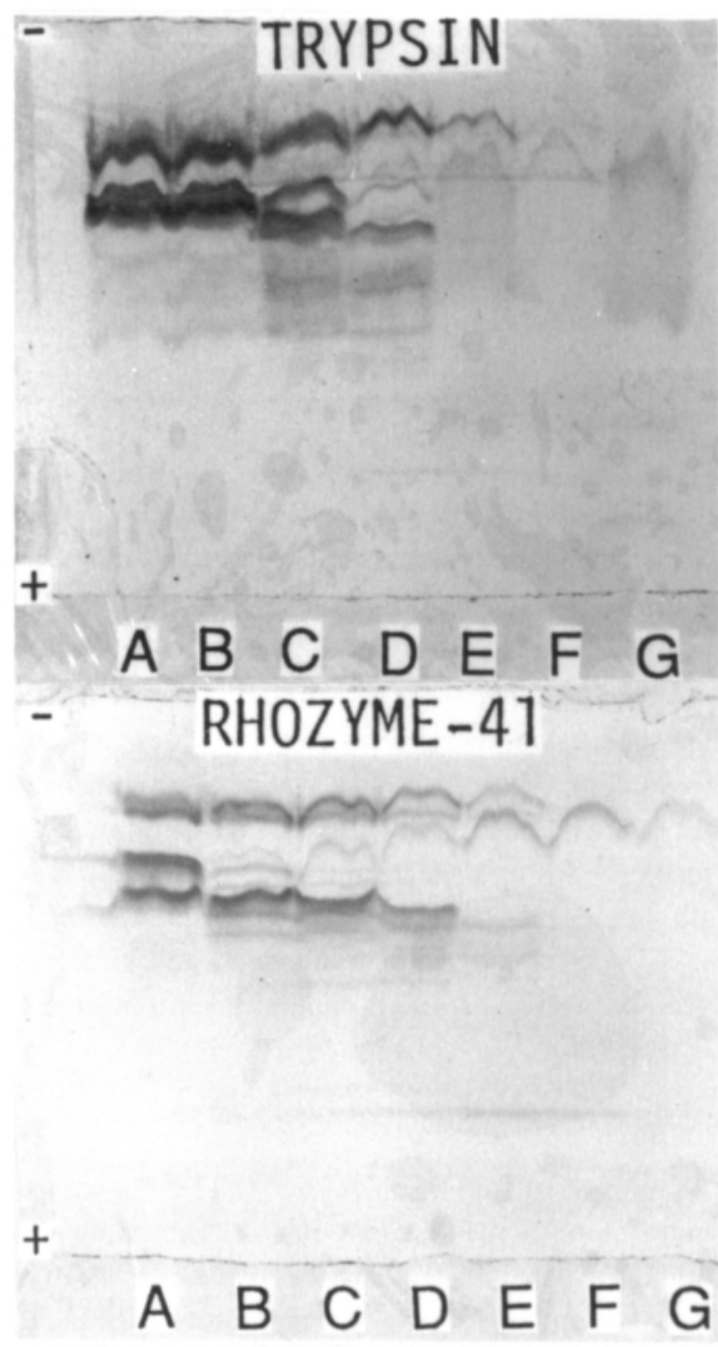

Fig. 2. Polyacrylamide gel electrophoresis of casein hydrolysates. A, B, C, D, E, F and G represent control, 10, 20, 30, $60,120,180$ and 240 min samples, respectively. (Photo: $\mathrm{Z}$. U. Haque.)

more potent (Fig. 5). This effect was markedly enhanced when the peptide content was increased to $20 \%$ (w/w casein); Na-Cas-P- $\mathrm{Rh}_{41}$ decreased the activity rate by almost $32 \%$. Data indicate that the hydrolytic activity of this enzyme is very much inhibited by the peptides this enzyme itself generates. Earlier, we observed that $\mathrm{Na}-\mathrm{Cas}-\mathrm{P}-\mathrm{Rh}_{41}$ are highly amphipathic and surface active (soap-like) (HAQUE 1991a, b). On the contrary, Na-Cas-P-Plasmin appeared to elevate the activity slightly at all stages of the reaction. This was true at both the 


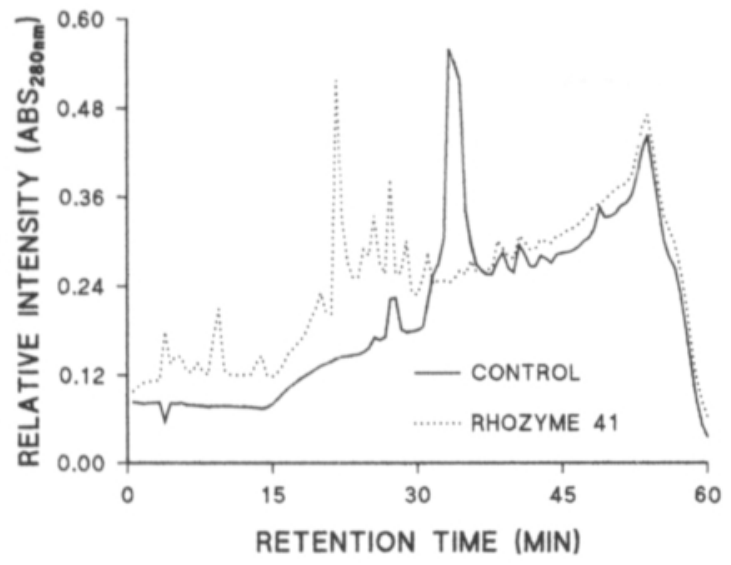

Fig. 3. Reverse phase high performance liquid chromatography of casein hydrolysate using $\mathrm{Rh}_{41}$. Peptide peaks with low retention time are smaller and/or less hydrophobic.

peptide concentrations. We have previously observed that PL produces comparatively large and highly surface active peptides from casein (HAQUE 1991). Perhaps these peptides were a ready substrate for $\mathrm{Rh}_{41}$.

The precursor for PL is indigenous to milk. Thus it is possible that PL indirectly influences flavor and texture by providing large peptides that easily broken down by other proteases in milk. It has been reported that plasmin digestion of casein markedly influences the quality of cheese and other dairy products (BASTIAN et al. 1991).

To further understand the influence of slow acting enzymes that are typically used in the accelerated cheese ripening processes, $\mathrm{Neu}$, a neutral peptidase used in accelerated cheese ripening, was used next. The uptake of sodium hydroxide after 300 seconds of incubation time was only 14 mole per gram of protein showlng that this enzyme was slow compared to $\mathrm{Rh}_{41}$ and TRY. The effect of the peptides on activity of NEU was the most marked compared to all the other enzymes tested. At the lower concentration of $10 \%$, the depression in activity was in the order Na-Cas-P-Neu $>$ Na-Cas-P$\mathrm{Rh}_{41}>\mathrm{Na}$-Cas-P-Plasmin. At the higher concentration of peptides $(20 \%)$, Na-Cas-P-Rh $\mathrm{Rh}_{41}$ was the most detrimental and depressec Neu activity rate by $50 \%$ at an incubation time of $300 \mathrm{sec}$ (Fig. 6).
The activity of PL is very low to begin with. Added peptides further depressed the activity by a maximum ( $20 \%$ peptide, w/w protein) of about $14 \%$ at an incubation time of $300 \mathrm{sec}$. At the higher peptide concentration, the depression of activity was clearly seen, for Na-Cas-P-Rh $\mathrm{R}_{41}$ and $\mathrm{Na}-\mathrm{Cas}-\mathrm{P}$ Neu, throughout the incubation (Fig. 7).

Data indicate that in all the above enzymes, $\mathrm{Na}$ Cas-P- $\mathrm{Rh}_{41}$ was the most effective in depressing activity. The inhibitive activity on a percentile basis was the cheese ripening enzymes (NEU and $\mathrm{Rh}_{41}$ ).

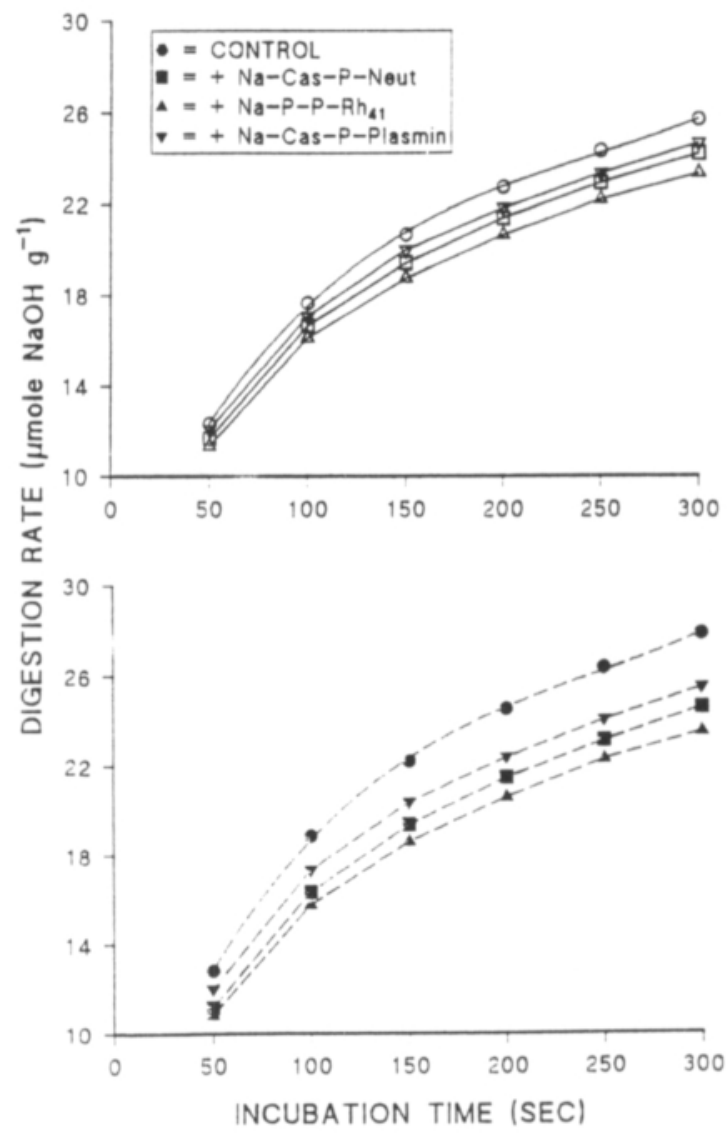

Fig. 4. Effect of various milk peptides on the digestibility of sodium caseinate with trypsin. The peptide concentration was $10 \%$ (open symbols) and $20 \%$ (solid symbols) (wt/wt of protein). The control samples had an equal amount of added sodium casein that had been passed though all the steps used in the production of peptides without the addition of the enzyme. Freshly prepared enzyme solutions were used at a enzyme to protein ratio of 1:200. The $\mathrm{X}$-axis represents the incubation time at $37^{\circ} \mathrm{C}$ and the $\mathrm{Y}$-axis is the digestion rate. 


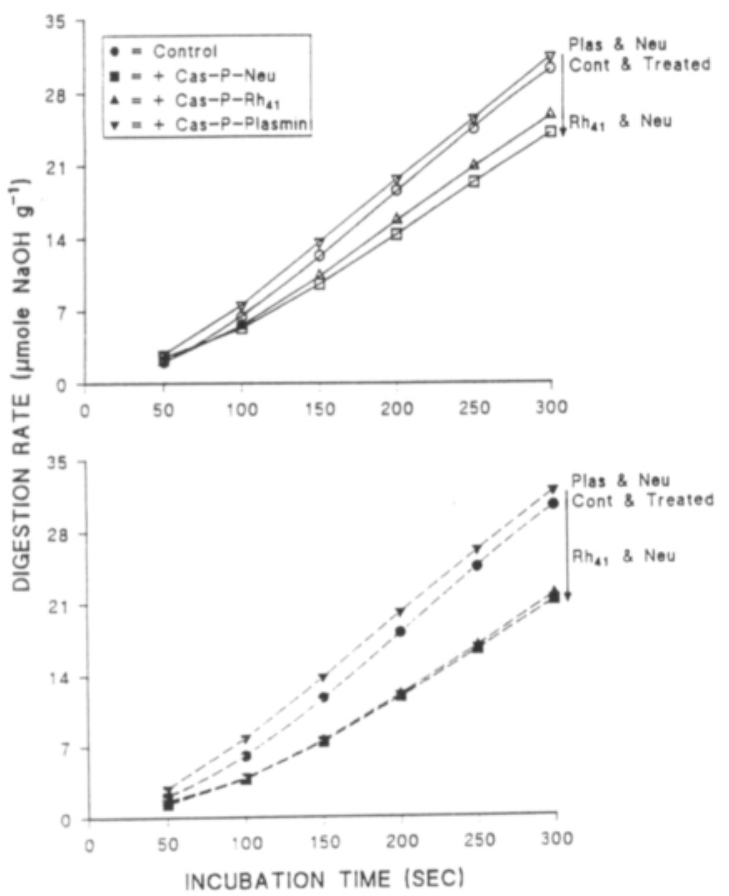

Fig. 5. Effect of various milk peptides on the digestibility of sodium caseinate with plasmin. All conditions and descriptions are the same as in Fig. 4.

\section{Effect of indigenous milk peptides on the digestibility of caseinate}

The crude peptide preparations from WPC markedly reduced the activity of $\mathrm{Rh}_{41}$ (Fig. 8). This depression of enzyme activity was directly related to the concentration (ultrafiltration $\{\mathrm{UF}\}$ ) of the whey proteins at a peptide concentration of $10 \%$ (w/w protein). Data indicate that certain peptides that are concentrated by UF concentration inhibit the activity of $\mathrm{Rh}_{41}$. When powerful protease, TRY, was used, the activity was modulated by the UF

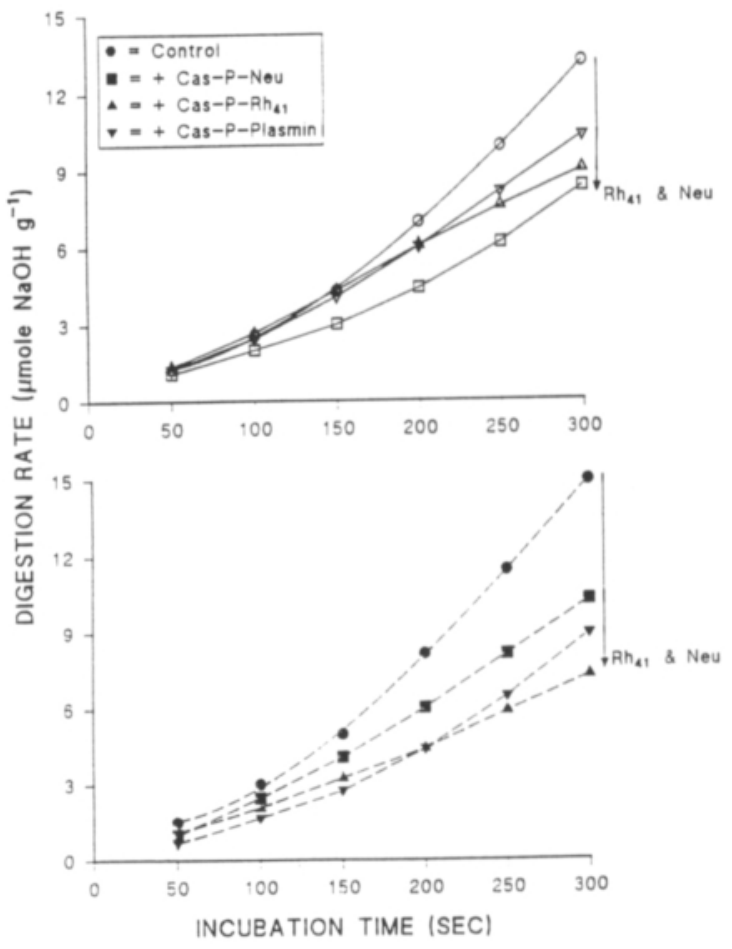

Fig. 6. Effect of various milk peptides on the digestibility of sodium caseinate with Rhozyme $41\left(\mathrm{Rh}_{41}\right)$. All conditions and descriptions are the same as in Fig. 4.

peptides but they did not seem to be directly affected.

The amphipathic nature of whey peptides has been illustrated by us earlier (HAQUE 1991, 1993). More recently, we have isolated and seguenced the major amphipathic peptides from whey. The major peptide originates from $\beta$-casein (HAQUE et al. 1993).

Acknowledgements. Funds for author Haque's research and visiting professorship to Finland were provided by the Agricultural Research Centre and the Finnish Academy. Expert technical help by the staff of the Food Research Istitute, $\mathrm{ARC}$, is deeply appreciated. 


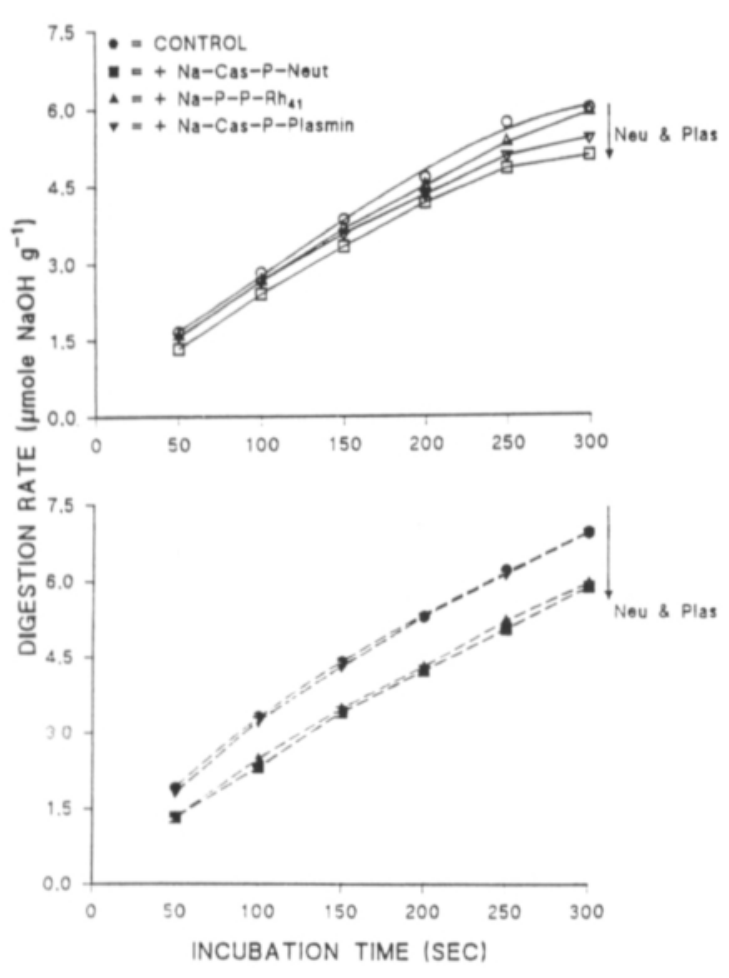

Fig. 7. Effect of various milk peptides on the digestibility of sodium caseinate with Neutrase. All conditions and descriptions are the same as in Fig. 4.

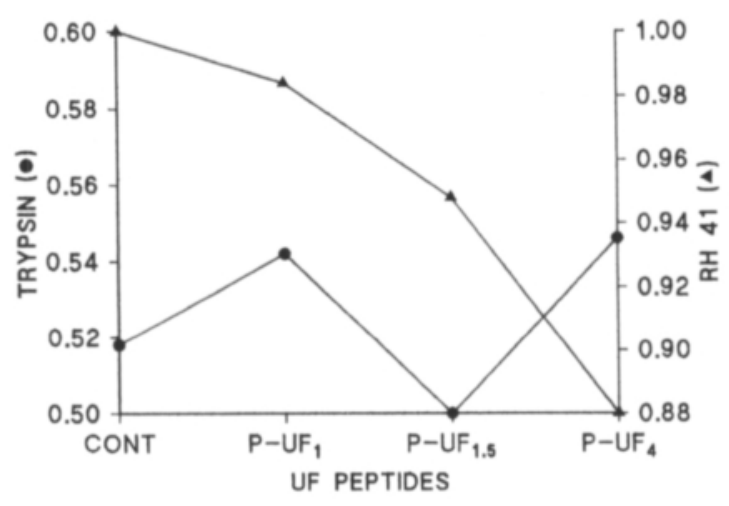

Fig. 8. Effect of indigenous peptides $(\mathrm{P})$ on the digestibility of sodium caseinate. The peptides were obtained as described in Fig. 1 from whey protein concentrate (WPC), at various levels of concentration. The enzymes used were trypsin and Rhozyme 41 ( $\left.\mathrm{Rh}_{41}\right)$, a cheese ripening enzyme. The labels on the Y-axis describe the peptides obtained from WPC at various levels of concentration by ultrafiltration (UF), i.e., 1 fold is $\mathrm{UF}_{1}, 1.5$ fold is $\mathrm{UF}_{1.5}$, and 4 fold is $\mathrm{UF}_{4}$. The $\mathrm{Y}-1$ and 2-axis represent the hydrolysis rate for trypsin and $\mathrm{Rh}_{41}$, respectively.

\section{References}

Antil.a, P., Haque, Z.U. \& Kinsella, J.E. 1987. Assessment of the in-vitro digestibility of casein using the phstat method the effect of alkali heat treatments and iron addition. Milchwissenschaft 42: 485 .

BANKS, J.M., GRIFFITHS, M.W., PHILliPS, J.D. \& MUIR, D.D. 1988. A comparison of the effects of storage of raw milk at 2 degree $\mathrm{C}$ and 6 degree $\mathrm{C}$ on the yield and quallty of Cheddar cheese. Food. Microbiol. 5: 9.

Bastian, E.D., Hansen, K.G. \& Brown, R.J. 1991. Activation of plasmin with urokinase in ultrafiltered milk for cheese manufacture. J. Dairy Sci. 74: 3669.

BEST, D. 1987. Enzymes, yeasts and flavors.; Prep-Foods. Chicago, I11. Gorman Publishing Company. 157, 5: 144-146, 151. ill.

Christensen, T.M.I.E., Kristiansen, K.R. \& MADSEN, J.S. 1989. Proteolysis in cheese investigated by high performance liquid chromatography. J. Dairy. Res. 56: 823.

Exterkate, F.A., DeVeer, G.J.C.M. \& Stadhouders, J. 1987. Acceleration of the ripening process of gauda cheese by using thermoshock (TS) treated mixed strain starter cells: Short surve of the results obtained and future possibilities. Bull. IDF 209: 48.

FoX , P.F. 1989. Acceleration of cheese ripening. Food Biotechnol. 2: 133.

Friester, H., Meisel, H. \& SCHLImME, E. 1989. Application of the modified OPA method in the analysis of whey proteins and caseins as well as their hydrolytic and proteolytic products. J. Dairy. Res. 56: 554.

HAQUE, Z.U. 1991a. Importance of peptides for food proteIn functionality. In: Food polymers, gels and colloids. R. Soc. Chem., London, Engl. p. 159-170.

- 1991b. Physicochemical and biological properties of milk proteins and peptides. Proceedings of the 2nd ARRC International Symposium: Application of New Technology in Animal Industry. Animal Resources Research Center, Kon-Kuk Univ., Seoul, Korea. p. 175-192

- 1993. Influence of milk peptides in determining the functionality of milk priteins: A review. J. Dairy Sci. 76: 311. 
- ANTILA, P. \& ANTILA, V. 1993. Fractionation, identification and functionality of idigenous amphipathic peptides in edam whey. J. Dairy Sci. : in prep.

— \& BohouA, G.L. 1990. Effect of peptides on protein interfacial function. Food Technol. 44: 188.

— \& KinSElLA, J.E. 1988. Emulsifying properties of food proteins: effect of milk peptides on the emulsifying activity of delipidated milk proteins and -lactoglobulin Milchwissenschaft 43: 236.

— \& Mozaffar, Z. 1992a. Casein hydrolysate: 1. Continuous production using immobilized enzyme bioreactors. Food Hydrocolloids 5: 549.

— \& MoZAFFAR Z. 1992b. Casein hydrolysate: 2. Functional properties of peptides. Food Hydrocolloids 5: 559.

Hung, N.D., VAS, M., CSEKE, E. \& Szabolcsi, G. 1984 Relative tryptic digestion rates of food proteins. J. Food Sci. 49: 1535.

Hurrell, R.F., LynCh, S.R., Trinidad, T.P., Dassenko, S.A. \& COOK, J.D. 1989. Iron absorption in humans as influenced by bovine milk proteins. Am, J. Clin. Nutr. 49: 546 ,

LAw, B.A. 1981. Accelerated ripening of Cheddar cheese with microbial proteinases. Neth. Milk. Dairy. J. 35: 313

— \& WIGMORE, A. 1982. Accelerated cheese ripening with food grade proteinases. J. Dairy. Res. 49: 137.

— \& WigmoRE, A.S. 1983. Accelerated ripening of Cheddar cheese with a commercial proteinase and intracellular enzymes from starter streptococci. J. Dairy. Res. 50: 519

LE-BARS, D. \& GRIPON, J.C. 1989. Specificity of plasmin towards bovine alpha S2-casein. J. Dairy. Res. 56: 817.

Linde, S.G., Bester, B.H. \& Wolmarans, H.P. 1989. The effect of ripening temperature on late blowing some other bacterial groups and ripening of gouda cheese. S. Afr. Dairy. Sci. 21: 61.

MORIHARA, K. 1974. Comparative specificity of microbial proteases. Adv. Enzymol. 41: 179.
Neurath, H. 1985. Proteolytic enzymes, past and present. Fed. Proc. Fed. Am. Soc. Exp. Biol. 44: 2907.

Pahkala, E., Antila, V. \& LaukKanen, M. 1984. Accelerating the ripening of cheese by the addition of proteolytic enzymes, 1. The characteristics of the enzyme. Meijeritieteellinen Aikakauskirja 42: 1-20.

VISSER, S. 1981. Proteolytic enzymes and their action on milk proteins. A review. Neth. Milk. Dairy. J. 35: 65.

—, Slangen, K.J., Hup, G. \& Stadhouders, J. 1983. Bitter flavour in cheese. 3. Comparative gelchromatographic analysis of hydrophobic peptide fractions from twelve Gouda-type cheeses and identification of bitter peptides isolated from a cheese made with Streptococcus cremoris strain HP. Neth. Milk. Dairy. J. 37: 181.

Wong, N.P., Jenness, R., Keebey, M. \& MARTH , E.H. 1988. Fundamentals of dairy chemistry. 3rd ed. Van Nostrand Reinhold, Co., New York, NY.

YELLIN, A.K. 1986. Enzymes-the movers and shakers of our body chemistry. FDA. consum. 20: 10.

Zevaco, C. \& DesmazeAud, M.J. 1980. Hydrolysis of beta casein and peptides by intracellular neutral protease of Streptococcus diacetylactis. J. Dairy Sci. 63: 15.

\section{Manuscript received November 1993}

Zahur U. Haque

Department of Food Science and Technology

Box 9805, MAFES, Mississippi State University

MS 39762, USA

Pirkko Antila

Department of Food Technology, Dairy Science

Box 27

FIN-00014 University of Helsinki, Finland

\title{
SELOSTUS
}

\section{Maidon valkuaisen peptidit: vaikutus natriumkaseinaattiin}

\author{
Zahur U. Haque ja Pirkko Antila
}

Mississippi State University ja Helsingin yliopisto

Tutkimuksessa hydrolysoitiin natriumkaseinaatti $(\mathrm{NaCN})$ Rhozyme41:llä (Rh41), Neutrasilla (Neu) ja plasmiinilla (PL), jolloin saatiin seuraavat peptidiyhdisteet: $\mathrm{Na}-\mathrm{Cas}-\mathrm{P}$ $\mathrm{Rh}_{4}$ I, Na-Cas-P-Neu ja Na-Cas-P-PL.

Alkuperäiset herapeptidit (indigenous whey proteins = IWP) saatiin tuoreesta herasta saostusmenetelmällä. Näitä peptidifraktioita käytettiin tutkittaessa maidon peptidien vaikutusta eräiden proteaasien aktiivisuuksiin. Kaikki tutkitut peptidifraktiot alensivat entsyymiaktiivisuuksia. Na-CasP-Rh4l oli voimakkain entsyymiaktii-visuuden heikentäjä, sillä se alensi trypsiini-, Rh41-, Neu- ja PL-aktiivisuuksia 15 , 32,50 ja $14 \%$. IWP alensi selvästi Rh41-aktiivisuutta. Heran ultrasuodatus-konsentraatiotaso oli suoraan verrannollinen entsyymi-inhibition voimakkuuteen. 